Diabetologia 10, 555-558 (1974)

(C) by Springer-Verlag 1974

\title{
Hepatic and Renal Protein Synthesis in Normal, Diabetic and Ketotic Chinese Hamsters
}

\author{
Albert Y. Chang \\ Diabetes and Atherosclerosis Research, The Upjohn Co., Kalamazoo, MI 49001, USA
}

\begin{abstract}
Summary. Two aspects of protein synthesis were studied in vitro in tissue extracts prepared from normal, diabetic and ketotic Chinese hamsters. Firstly, the activity to support polyuridylic acid (poly U)-dependent polyphenylalanine synthesis from ${ }^{14} \mathrm{C}-$ phenylalaninetRNA was measured in the liver ribosomes and no significant difference was observed between diabetic hamsters $(0.310 \pm 0.007 \mathrm{nCi} / \mathrm{min} / \mathrm{mg}$ ribosomal proteins $)$ and their controls $(0.325 \pm 0.015)$, or between ketotic hamsters $(0.256 \pm 0.013)$ and their controls $(0.274 \pm 0.018)$. Secondly, activity in protein synthesis with endogenous mRNA's was followed in the postmitochondrial supernatant (PMS) fraction after the removal of endogenous amino acid pools by gel filtration. The rate of amino acid incorporation was measured in both liver and kidnoy extracts with ${ }^{14} \mathrm{C}$-leucine, lysine, serine, or glycine as labels. The initial rates of incorporations in the diabetic liver PMS (Leu $=8.01+1.64 \mathrm{pmole} / \mathrm{min} / \mathrm{mg}$ protein; $L y s=2.90 \pm 0.56 ;$ Ser $=3.40 \pm 0.60 ; G l y=3.34 \pm 0.66)$,
\end{abstract}

and in the ketotic PMS ( Leu $=8.48+2.06 ;$ Lys $=3.49 \pm$ $0.82 ;$ Ser $=4.11 \pm 0.80 ; G l y=3.73 \pm 0.81$ ) were similar to those in the matched controls (Leu $=8.60 \pm 1.06 ;$ Lys $=3.14 \pm 0.37 ;$ Ser $=3.70 \pm 0.54 ; G l y=3.38 \pm 0.37)$. Likewise, the amino acid incorporations in the diabetic kidney PMS $($ Leu $=4.38+1.09 ;$ Lys $=1.26+0.28 ; \mathrm{Ser}=$ $1.98 \pm 0.29 ; G l y=1.81 \pm 0.32)$, and in the ketotic kidney $\operatorname{PMS}($ Leu $=5.39 \pm 1.29 ;$ Lys $=1.79 \pm 0.4 ;$ Ser $=1.9 \pm$ $0.18 ; G l y=1.97 \pm 0.15$ ) were not significantly different from those in the normals (Leu $=5.32 \pm 0.56 ; L y s=$ $1.60 \pm 0.19 ; \mathrm{Ser}=2.06 \pm 0.22 ; G l y=2.02 \pm 0.18)$. It is concluded that the diabetic and ketotic Chinese hamsters retain normal activity in the reported two aspects of protein synthesis.

Key words: Spontaneous diabetes, streptozotocin, ribosomes, hepatic and renal protein synthesis Chinese hamsters, postmitochondrial supernatant, polyuridylic acid-dependent polyphenylalanine synthesis
Several groups of investigators have reported a decrease in the eapacity of microsomal preparations from the livers of chemically or insulin antibodyinduced diabetic rats $[1-6]$. In these acutely insulindeficient animals, the hepatocytes had low polysome content $[2,3]$ associated with disorganization and loss of rough endoplasmic reticulum [5]. Using crude hepatic postmitochondrial supernatant (PMS) fractions, Pain demonstrated a direct inhibitory effect of acute insulin deficiency at the level of peptide chain initiation [6]. The hepatic supernatant protein content and the levels of several hepatic enzymes were found to be in excess in the Chinese hamsters with long term diabetes [7]. Severe renal ultrastructural changes, particularly in thickening of the capillary basement membranes, were also reported in the diabetic Chinese hamsters [8]. Therefore, it is of importance to study the protein synthesis apparatus in both liver and kidney of the Chinese hamsters. This report summarizes our studies on the capacity of hamster liver and kidney PMS preparations to incorporate amino acids and of liver ribosomes to support poly Udirected polyphenylalanine synthesis.

\section{Materials and Methods}

\section{Animals}

The animals ranged in age from 7 to 18 months and were selected from the Upjohn colony. The "ketotic" hamsters showed positive results on Ketostix ${ }^{\oplus}$ and the "diabetic" hamsters were negative to Ketostix. Both groups showed Testape ${ }^{\circledR}$ values of 4 - within two months after birth and consistently thereafter. All these animals were matched with nondiabetic animals of the same age and sex.

\section{Preparation of Ribosomes}

The animals were killed by decapitation; the livers were quickly excised and placed immediately in cold Medium $A(0.25 \mathrm{M}$ sucrose, $0.1 \mathrm{M} \mathrm{KCl}, 0.005 \mathrm{M}$ $\mathrm{Mg}$-acetate, $0.006 \mathrm{M}$ mercaptoethanol and $0.05 \mathrm{M}$ Tris$\mathrm{Cl}, \mathrm{pH}$ 7.5). The livers were minced and homogenized in 2 volumes of Medium $A$ in a glass homogenizer fitted with a Teflon-pestle. After centrifugation at $6,000 \times g$ for $10 \mathrm{~min}$, the supernatant was decanted and further centrifuged at $20000 \times g$ for $10 \mathrm{~min}$. To each $\mathrm{ml}$ of supernatant collected, $0.15 \mathrm{ml}$ of $10 \%$ sodium deoxycholate was added. After standing in ice for $1 \mathrm{hr}$ with occasional stirring, the solution was centrifuged at $105000 \times g$ for $2 \mathrm{hrs}$. The ribosomal pellets were suspended and homogenized in a small volume of buffer containing $0.35 \mathrm{M}$ sucrose, $0.07 \mathrm{M}$ $\mathrm{KCl}, 0.004 \mathrm{M}, \mathrm{MgCl}_{2}, 0.006 \mathrm{M}$ mereaptoethanol and $0.05 \mathrm{M}$ Tris- $\mathrm{Cl}, \mathrm{pH}$ 7.8. Protein was determined. according to Lowry et $a l$. [9] and adjusted to a concentration of $3.0 \mathrm{mg} / \mathrm{ml}$.

\section{Preparation of Rat Liver " $p H 5$ Enzyme"}

Freshly excised livers from Upj = TUC (SD) spf rats were homogenized in 2.3 volumes of cold Medium $B\left(0.35 \mathrm{M}\right.$ sucrose, $0.035 \mathrm{M} \mathrm{KHCO}_{3}, 0.004 \mathrm{M} \mathrm{MgCl}_{2}$ and $0.025 \mathrm{M} \mathrm{KCl}$ ). The homogenate was centrifuged at $15000 \times g$ for $10 \mathrm{~min}$ and the supernatant was 
diluted with 3 volumes of cold Medium $C(0.90 \mathrm{M}$ sucrose, $0.004 \mathrm{M} \mathrm{MgCl}_{2}$ and $0.025 \mathrm{M} \mathrm{KCl}$ ). The sample was centrifuged at $100,000 \times \mathrm{g}$ for $70 \mathrm{~min}$ and the supernatant was diluted further with equal volume of Medium $C$ and slowly adjusted to $\mathrm{pH} 5.0$ by adding dropwise cold $1.0 \mathrm{M}$ acetic acid. The mixture was stirred for $1 \mathrm{~h}$ at $4^{\circ} \mathrm{C}$. The precipitates collected were washed once with Medium $C$ and dissolved in Medium $B$. The preparation was frozen in small aliquots.

\section{Preparation of Postmitochondrial Supernatant (PMS)}

Freshly excised livers or kidney cortices from the Chinese hamsters were homogenized in 2 volumes of Medium $A$ and centrifuged at $10,000 \times \mathrm{g}$ for $10 \mathrm{~min}$. One $\mathrm{ml}$ of supernatant was filtered through a Sephadex G25 column $(0.9 \times 30 \mathrm{~cm})$ equilibrated with Medium $A$. The materials collected in the excluded volume were designated as the PMS fraction and assayed immediately for activity to incorporate amino acids into proteins. Protein content in PMS was determined according to Lowry et al. [9].

\section{Protein Synthesis Assay}

The preincubation medium for poly U-dependent polyphenylalanine synthesis contained $0.2 \mathrm{ml}$ of reaction mixture $A(0.39 \mathrm{M}$ sucrose, $0.12 \mathrm{M}$ Tris-Cl, pH 7.5, $0.012 \mathrm{M} \mathrm{MgCl}_{2}, 0.17 \mathrm{M} \mathrm{KCl}, 2.4 \mathrm{mM}$ ATP, $0.24 \mathrm{mM}$ GTP, $0.0146 \mathrm{M}$ mercaptoethanol, $2.4 \mathrm{mM}$ phosphoenolpyruvate and $20 \mu \mathrm{g}$ pyruvate kinase), $0.1 \mathrm{ml}$ ribosome suspensions and $0.15 \mathrm{ml}$ rat liver "pH 5 enzyme". After preincubation at $37^{\circ} \mathrm{C}$ for $30 \mathrm{~min}, 0.1 \mathrm{ml}$ of reaction mixture $B(4.5 \mathrm{mM} \mathrm{ATP}$, $0.45 \mathrm{mM}$ GTP, $4.5 \mathrm{mM} \mathrm{MgCl}_{2}$, $4.5 \mathrm{mM}$ phosphoenolpyruvate, $10 \mu \mathrm{g}$ pyruvate kinase, $90 \mu \mathrm{g}$ poly $\mathrm{U}, 7 \mu \mathrm{g}$ ${ }^{14} \mathrm{C}$-phenylalanine-tRNA, $1.6 \mu \mathrm{Ci} / \mathrm{mg}$ ) was added to the sample. The reaction was allowed to proceed at $37^{\circ} \mathrm{C}$ and terminated by transferring $0.1 \mathrm{ml}$ aliquots to a test tube containing $0.1 \mathrm{ml}$ of $10 \mathrm{mg} / \mathrm{ml}$ bovine serum albumin and immediately followed by adding $2.0 \mathrm{ml}$ cold $10 \%$ TCA containing $2 \mathrm{mM}$ unlabelled phenylalanine.

The postmitochondrial supernatant fractions prepared from liver and kidney cortex were assayed for amino acid incorporating activity with ${ }^{14} \mathrm{C}$-labelled glycine, leucine, lysine or serine. The reaction mixture was made of $0.1 \mathrm{ml}$ of PMS fraction, $0.11 \mathrm{ml}$ of $0.12 \mathrm{mM}$ ${ }^{14} \mathrm{C}$-labelled amino acid in Medium $D(0.1 \mathrm{M} \mathrm{KCl}$, $0.005 \mathrm{M} \mathrm{Mg}$-acetate, $0.006 \mathrm{M}$ mercaptoethanol, $0.05 \mathrm{M}$ Tris-Cl, pH 7.5), $0.11 \mathrm{ml}$ of $0.12 \mathrm{mM} 19$ other amino acids in Medium $D$ and $0.11 \mathrm{ml}$ of Medium $D$ containing $4 \mathrm{mM}$ ATP, $0.8 \mathrm{mM}$ GTP, $20 \mathrm{mM}$ phosphoenolpyruvate and $100 \mu \mathrm{g}$ pyruvate kinase. The reaction was allowed to proceed at $37^{\circ} \mathrm{C}$ and terminated as mentioned above with $10 \%$ TCA containing $2 \mathrm{mM}$ unlabelled specific amino acid.

The precipitates collected were suspended in $0.5 \mathrm{ml}$ of $0.5 \mathrm{M}$ glycine- $\mathrm{NaOH}, \mathrm{pH} 10.4$ and incubated at $37^{\circ} \mathrm{C}$ for $2 \mathrm{~h}$. Two $\mathrm{ml}$ of cold $10 \%$ TCA containing
$2 \mathrm{mM}$ unlabelled specific amino acid was added to the mixture. The precipitates were further washed twice with $2 \mathrm{ml} \mathrm{10 \%} \mathrm{TCA,} \mathrm{dissolved} \mathrm{in} 1.0 \mathrm{ml}$ NCS Tissue Solubilizer ${ }^{\circledR}$ (Amersham/Searle) and counted in $15 \mathrm{ml}$ Bray's solution [10]. Quenching was corrected by channel ratio method [11].

\section{Results}

\section{Poly U-Dependent Polyphenylalanine Synthesis}

The liver ribosomes used in this study were isolated in the presence of sodium deoxycholate and the ribosomes were further preincubated for $30 \mathrm{~min}$ in order to ensure that they were devoid of any residual endogenous mRNA activities. The diabetic and ketotic animals chosen for this experiment had shown consistent $4+$ (Testape ${ }^{\circledR}$ ) glucosuria for at least 8 months and their fasting blood sugar levels on the day of the experiment ranged from 160 to $600 \mathrm{mg} \%$. The rate of poly U-dependent polyphenylalanine synthesis in the liver ribosomes was assayed with ${ }^{14} \mathrm{C}$-phenylalanine-tRNA as reactants and the TCA-precipitable products were extensively washed and treated with alkali to break down the reactants. In each experiment, a time course was run and the linear portion was used to calculate the initial rate of incorporation. In a study with six pairs of Chinese hamsters, the rate of ${ }^{14} \mathrm{C}$-phenylalanine incorporation in the liver ribosomes of the diabetics was not significantly different from their matched controls (Table 1). Similarly, the liver ribosomes of ketotic Chinese hamsters and of their controls yielded similar results in poly U-dependent polyphenylalanine synthesis (Table 2).

\section{Rate of Amino Acid Incorporations in the Postmito- chondrial Supernatant ( $P M S$ ) Fractions}

PMS preparations from livers and kidneys of hamsters, devoid of amino acid pools by means of gel filtration, were assayed for the rate of incorporation of ${ }^{14} \mathrm{C}$-leucine, ${ }^{14} \mathrm{C}$-lysine, ${ }^{14} \mathrm{C}$-serine and ${ }^{14} \mathrm{C}$-glycine into proteins. In both liver and kidney PMS fractions, leucine was incorporated at the highest rate and the other three amino acids at similar rates (Table 3 ). The liver PMS showed higher protein synthetic activity than the kidney fraction and the liver/kidney ratios were highest for lysine $(2.07 \pm 0.11)$ and lowest for leucine $(1.67 \pm 0.08)$. In the study with five sets of matched Chinese hamsters, the hepatic and renal protein synthetic activities, measured in terms of the rate of incorporation of leucine, lysine, serine or glycine in the PMS fractions, were found to be similar in diabetic, ketotic and control animals (Table 3 ).

\section{Discussion}

The purpose of this study is to determine if the diabetic and ketotic Chinese hamsters are defective 
in hepatic and renal protein synthesis whereof two aspects were examined: the ability of hepatic ribosomes to support poly U-dependent polyphenylalanine synthesis and the activity of hepatic and renal PMS to incorporate amino acids into proteins.

The experimental results obtained in this study on the rate of transfer of phenylalanine from phenylalanine-tRNA into acid-insoluble products indicated in amino acid incorporation [12] and its ability to carry out peptide chain initiations [6]. ${ }^{14} \mathrm{C}$-labelled leucine, lysine and serine were selected because they represent different types of amino acids with individual biosynthetic pathways. GIycine was also included since it is present in an exceptionally large proportion in renal glomerular basement membrane which rates special attention due to its involvement in diabetic

Table 1. Poly $U$-dependent polyphenylalanine synthesis by diabetic and control Chinese hamster liver ribosomes

\begin{tabular}{|c|c|c|c|c|c|}
\hline Type & $\begin{array}{l}\text { No. } \\
\text { animals }\end{array}$ & Age & Sex & $\begin{array}{l}\text { Fasting } \\
\text { Blood } \\
\text { Glucose }\end{array}$ & $\begin{array}{l}\text { Rate of } \\
{ }_{14} \text { C-phenylalanine } \\
\text { Incorporation }\end{array}$ \\
\hline & & months & & $\mathrm{mg} \% \pm$ S. E.M. & $\begin{array}{l}\mathrm{nCi} / \mathrm{min} / \mathrm{mg} \text { ribosomal } \\
\text { proteins } \pm \mathrm{S} \text {. E.M. }\end{array}$ \\
\hline $\begin{array}{l}\text { Control } \\
\text { Diabetic }\end{array}$ & $\begin{array}{l}6 \\
6\end{array}$ & $\begin{array}{l}10-18 \\
10-18\end{array}$ & $\begin{array}{l}4 \mathrm{~F} 2 \mathrm{M} \\
4 \mathrm{~F} 2 \mathrm{M}\end{array}$ & $\begin{array}{l}88.5 \pm 7.8 \\
224 \pm 25.4\end{array}$ & $\begin{array}{l}0.325 \pm 0.015 \\
0.310 \pm 0.007\end{array}$ \\
\hline
\end{tabular}

a Calculated from the linear portion of a time course carried out as described in "Materials and Methods" at $0,1,2$, 3 min.

b Standard error of the mean.

Table 2. Poly U-dependent polyphenylalanine synthesis by ketotic and control Chinese hamster liver ribosomes

\begin{tabular}{|c|c|c|c|c|c|}
\hline Туре & $\begin{array}{l}\text { No. } \\
\text { animals }\end{array}$ & Age & Sex & $\begin{array}{l}\text { Fasting } \\
\text { Blood } \\
\text { Glucose }\end{array}$ & $\begin{array}{l}\text { Rate of } \\
{ }^{14} \mathrm{C} \text {-phenylalanine } \\
\text { Incorporation }^{\mathrm{a}}\end{array}$ \\
\hline & & months & & mg\%士s.E.M.b & $\begin{array}{l}\mathrm{nCi} / \min / \mathrm{mg} \text { ribosoma } \\
\text { proteins } \pm \text { S.E.M. }\end{array}$ \\
\hline $\begin{array}{l}\text { Control } \\
\text { Ketotic }\end{array}$ & $\begin{array}{l}6 \\
6\end{array}$ & $\begin{array}{l}10-17 \\
10-17\end{array}$ & $\begin{array}{l}4 \mathrm{~F} 2 \mathrm{M} \\
4 \mathrm{~F} 2 \mathrm{M}\end{array}$ & $\begin{array}{l}89.6 \pm 2.5 \\
362 \pm 51.8\end{array}$ & $\begin{array}{l}0.274 \pm 0.018 \\
0.256 \pm 0.013\end{array}$ \\
\hline
\end{tabular}

a Calculated from the linear portion of a time course carried out as described in "Materials and Methods" at $0,2,5$, $10 \mathrm{~min}$.

$\mathrm{b}$ Standard error of the mean.

Table 3. Rate of amino acid incorporations in liver and kidney postmitochondrial supernatant fractions of control, diabetic, and ketotic Chinese hamsters

\begin{tabular}{|c|c|c|c|c|c|c|c|c|c|}
\hline \multirow{3}{*}{ Type } & \multirow{3}{*}{$\begin{array}{l}\text { Blood } \\
\text { glucose }\end{array}$} & \multicolumn{8}{|c|}{ Rate of amino acid incorporations ${ }^{b}$} \\
\hline & & \multicolumn{4}{|l|}{$\widehat{\text { liver }}$} & \multicolumn{4}{|l|}{ kidney } \\
\hline & & $\overline{\text { Leu }}$ & Lys & Ser & Gly & Leu & Lys & Ser & Gly \\
\hline Control & $108.2 \pm 7.9$ & $8.60 \pm 1.06$ & $3.14 \pm 0.37$ & $3.70 \pm 0.54$ & $3.38 \pm 0.37$ & $5.32 \pm 0.56$ & $1.60 \pm 0.19$ & $2.06 \pm 0.22$ & $2.02 \pm 0.18$ \\
\hline Diabetic & $285.6 \pm 37.1$ & $8.01 \pm 1.64$ & $2.90 \pm 0.56$ & $3.40 \doteq 0.60$ & $3.34 \pm 0.66$ & $4.38 \pm 1.09$ & $1.26 \pm 0.28$ & $1.97 \pm 0.29$ & $1.81 \pm 0.32$ \\
\hline
\end{tabular}

a Each group contained five Chinese hamsters, male, 7-9 months of age.

b Calculated from the linear portion of a time course carried out as described in "Materials and Methods" at $0,1,2,3$ min.

c Standard error of the mean.

no difference in the activity of hepatic ribosomes between diabetic hamsters and their matched controls or between ketotic hamsters and their normal counterparts. This finding agrees with the reported observation that bound liver ribosomes from normal and alloxan-induced diabetic rats showed similar protein synthetic activity as directed by poly $\mathrm{U}[5]$.

The PMS system was chosen to study the overall protein synthetic capacity because of its high activity complications [13]. The renal PMS fractions of diabetic or ketotic Chinese hamsters, however, showed similar rate of incorporation of amino acids as those of the normal animals. The failure to observe a high rate of glycine incorporation in the kidney extracts, relative to those of leucine, lysine and serine, points to the fact that little glomerular basement membrane-like proteins were made in the PMS system prepared from kidney cortex. The remarkable similarity in the 
relative rates of incorporation of the four amino acids suggests homology in the proteins produced in the renal and hepatic PMS fractions.

Analogous to the findings in the kidney extracts, there was no significant difference among normal, diabetic and ketotic liver PMS fractions in the rate of incorporation of amino acids per unit weight of PMS proteins. However, Pain had reported a reduced ability to incorporate leucine and phenylalanine into proteins, in terms of incorporation per unit ribosome, by PMS preparations from livers of streptozotocininduced diabetic rats [6]. The discordance may arise from the difference in units selected to express the activity of amino acid incorporation in these two reports. Alternatively, the disagreement may be due to an existing difference in the effects on protein synthetic capacity between streptozotocin-induced diabetes in rats and spontaneous diabetes in the Chinese hamsters. It is concluded from the present study that no detectable defect, regarding the two reported aspects of protein synthesis, is evident in the diabetic or ketotic Chinese hamster.

Acknowledgement. The author gratefully acknowledges the skillful technical assistance of Mrs. Diana I. Schneider.

\section{References}

1. Korner, A.: Alloxan diabetes and in vitro protein biosynthesis in rat liver microsomes and mitochondria. J. Endocr. 20, 256-265 (1960)

2. Tragl, K.H., Reaven, G.M.: Effect of experimental diabetes mellitus on protein synthesis by liver ribosomes. Diabetes 20, 27-32 (1971)

3. Tragl, K.H., Reaven, G.M.: Effect of insulin deficiency on hepatic ribosomal aggregation. Diabetes 21, $84-88(1972)$
4. Reaven, E.P., Peterson, D.T., Reaven, G.M.: The effect of experimental diabetes mellitus and insulin replacement on hepatic ultrastructure and protein synthesis. J. clin. Invest. 52, 248-262 (1973)

5. Peterson, D.T., Alford, F.P., Reaven, E.P., Ueyama, I., Reaven, G. M. : Characteristics of membrane-bound and free hepatic ribosomes from insulin-deficient rats, I. Acute experimental diabetes mellitus. J. clin. Invest. 52, 3201-3211 (1973)

6. Pain, V.M.: Protein synthesis in a postmitochondrial supernatant system from rat liver. An effect of diabetes at the level of peptide chain initiation. FEBS Letters 35, 169-172 (1973)

7. Chang, A. Y., Schneider, D.I. : Metabolic abnormalities in the pancreatic islets and livers of the diabetic Chinese hamster. Diabetologia 6, 180-185 (1970)

8. Conforti, A.: Kidney ultrastructure in spontaneous diabetes of the Chinese hamster. Acta diabet. lat. 9 , $655-687(1972)$

9. Lowry, O.H., Rosebrough, N.J., Farr, A.L., Randall, R.J.: Protein measurement with the Folin-phenol reagent. J. biol. Chem. 193, 265-275 (1951)

10. Bray, G. A. : A simple efficient liquid scintillation for counting aqueous solutions in a liquid scintillation counter. Analyt. Biochem. 1, 279-285 (1960)

11. Herberg, R.J.: Channel ratio method of quench correction in liquid scintillation counting. Packard Technical Bulletin No. 15 (1965)

12. Richardson, A., MeGown, E., Henderson, L. M., Swan, Pat.: In vitro amino acid incorporation by the postmitochondrial supernatant from rat liver. Biochim. biophys. Acta (Amst.) 254, 468-477 (1971)

13. Kefalides, N.A.: Biochemical properties of human glomerular basement membrane in normal and diabetic kidneys. J. clin. Invest. 53, 403-407 (1974)

Dr. Albert Y. Chang

Diabetes and Atherosclerosis

Research

The Upjohn Company

Kalamazoo, Michigan 49001

USA 